\title{
Comparison of three cold storage methods for Norway spruce (Picea abies Karst) bare root seedlings: consequences on metabolic activity of ectomycorrhizae assessed by radiorespirometry
}

\author{
K Al Abras, F Le Tacon, F Lapeyrie * \\ INRA, Centre de Recherches Forestières de Nancy, Champenoux, 54280 Seichamps, France
}

(Received 3 December 1990; accepted 7 June 1991)

\begin{abstract}
Summary - Bare root forest tree seedlings are very sensitive to environmental factors, including cold storage. The metabolic activity of 2 types of ectomycorrhizae of Norway spruce seedlings, after cold storage for 2 weeks under 3 experimental conditions, was compared using radiorespirometry. The mycorrhizal type BOO had a lower metabolic activity before treatment and, was more resistant to cold storage than the $\mathrm{A} 12$ type. These observations were in general agreement with previously published field experiments, where B00 became dominant and A12 was suppressed after cold storage and transplanting. Ectomycorrhizal fungi could be selected according to these criteria for controlled nursery inocculation. Storage at $4{ }^{\circ} \mathrm{C}$ in polyethylene bags did not affect the metabolic activity of ectomycorrhizae, unlike other storage conditions.
\end{abstract}

\section{seedlings / cold storage / ectomycorrhizae / Norway spruce / radiorespirometry / nursery}

Résumé - Comparaison de trois méthodes de conservation au froid de plants à racines nues d'épicéa commun (Picea abies Karst). Conséquences sur l'activité métabolique des ectomycorhizes. Les plants forestiers à racines nues sont particulièrement sensibles à tous les facteurs du milieu, y compris durant les périodes de stockage à basse température. Les mycorhizes contrôlant la nutrition minérale du plant in situ, les dommages qu'elles subissent lors des opérations de stockage sont très certainement une des composantes de la crise de transplantation. L'activité métabolique de 2 types d'ectomycorhizes associées à des plants d'épicéa commun a été comparée par radiorespirométrie après deux semaines de stockage au froid. Nous avons mesuré : le dégagement de ${ }^{14} \mathrm{CO}_{2}$ (fig 2) l'incorporation (fig 3) et l'absorption de ${ }^{14} \mathrm{C}$ (fig 4) par des mycorhizes excisées en présence de $[1.14 \mathrm{C}]$ glucose. Les plants ont été préalablement stockés durant deux semaines soit à $-4{ }^{\circ} \mathrm{C}$ en sacs de polyéthylène clos, soit à $+4{ }^{\circ} \mathrm{C}$ avec ou sans emballage. Avant stockage les mycorhizes de type B00 avaient une activité métabolique plus faible que celles de type A12, mais semblent mieux préservées après stockage. Ces résultats concordent avec des travaux publiés antérieurement et montrant que le type A12 avait une faible capacité à se maintenir sur le système racinaire des plants après stockage et transplantation, alors que le type BoO devenait dominant dans les mêmes conditions. L'aptitude des champignons mycorhiziens à résister au stockage pourrait être un critère supplémentaire de sélection des souches destinées à l'inoculation contrôlée des pépinières. Parmi les techniques de stockage comparées, seul un stockage à $+4^{\circ} \mathrm{C}$ en sacs de polyéthylène n'affecte l'activité métabolique d'aucun des deux types de mycorhizes étudiés.

plants / stockage au froid / ectomycorhizes / Epicéa commun / radiorespirométrie / pépinière

\footnotetext{
* Correspondence and reprints
} 


\section{INTRODUCTION}

Bare root forest trees seedlings are quite sensitive to environmental conditions from the time they are lifted from the nursery beds to the time they are set in the forest stand. The stress encountered by the root system during lifting and planting operations can cause serious losses in survival (Cossitt, 1961; Mullin, 1974). The storage period can sometimes be reduced to a minimum. However, when managing large nurseries or vast reforestation areas, it cannot be avoided. The most prevalent technique remains storage in cold room, either for several months between winter lifting and spring planting, or for only a few weeks after spring lifting.

Several cold storage methods have been used and compared in order to reduce plant damage (Lanquist and Doll, 1960; Wycoff, 1960; Harvey, 1961; Kahler and Gilmore, 1961; Mullin, 1966, 1980, 1983; Mullin and Parker, 1974; Nelson, 1980; Cram and Lindquist, 1982; Tisserat and Kuntz, 1984; Venator, 1985). These comparative studies were based on seedlings survival after plantation, and do not consider the physiological stress encountered during storage.

Seedling physiology has been recently investigated, especially as it is affected by lifting date and cold storage conditions on carbohydrate content, bud dormancy, shoot apical mitotic index, frost hardening, or dessication resistance (Ritchie et al, 1985; Cannell et al, 1990), but ectomycorrhizae, which control nutrition of trees in nurseries and after outplanting, have been overlooked.

In a previous study, we have shown that different ectomycorrhizal populations responded differently to storage stress, leading to regression or extension of these populations on the root system after plan- tation (Al Abras et al, 1988b). In this paper, we compare the metabolic activity of 2 types of Norway spruce ectomycorrhizae in seedlings subjected to cold storage. Radiorespirometry was used to characterize the metabolic activity of the ectomycorrhizae.

\section{MATERIALS AND METHODS}

\section{Plant material}

Four-year old bare root seedlings of Picea excelsa (Lam) Link, grown on a sandy soil in a commercial nursery (eastern France), were lifted in May, all at the same date, and eventually transferred to dark cold rooms $2 \mathrm{~h}$ later.

\section{Treatments}

Four treatments were applied to seedlings ( 30 plants per treatment) :

- Two weeks storage at $+4^{\circ} \mathrm{C}$ in closed polyethylene bags.

- Two weeks storage at $+4{ }^{\circ} \mathrm{C}$ and $98 \pm 5 \%$ humidity (in heap without bag).

-Two weeks storage at $-4{ }^{\circ} \mathrm{C}$ in closed polyethylene bags.

- No storage (The control plants were stored overnight at $4{ }^{\circ} \mathrm{C}$ before ectomycorrhizal sampling).

\section{Ectomycorrhizal sampling}

After 2 weeks cold storage or a few $h$ after lifting, the plants were brought to room temperature for $1 \mathrm{~h}$. The root systems were washed carefully under tap water to remove most of the soil particles. Ectomycorrhizae belonging to the dominant $\mathrm{A} 12$ and $\mathrm{B} 00$ types previously described (Al Abras, 1988), were sampled. Four subsamples of each mycorrhizal type per treat- 
ment were analysed separately using radiorespirometry.

A12 mycorrhizae are characterized by an abundant extramatrical mycelium. In cross section the mantle has 2 distinct layers: the outermost prosenchymateous layer of hyphae bear clamp connections and the innermost layer has a plectenchymatic structure. The well developed Hartig net extends to the endodermis (fig $1 \mathrm{a}, \mathrm{b}$ ).

B00 mycorrhizae are characterized by a smooth external surface, a very thin plectenchymatic mantle lacking clamp connections, and a well developed Hartig net extending to the endodermis (fig 1c, d).

\section{Radiorespirometry}

The radiochemical $[1-14 \mathrm{C}]$ glucose $(50 \mathrm{mCi} /$ mmol) was purchased from the Commissariat à l'Energie Atomique (Gif sur Yvette, France). The antibiotics aureomycin, penicillin, and streptomy- cin were from Sigma. All others chemicals were of analytical grade.

Respiration was quantified using a $10-\mathrm{ml}$ continuous ${ }^{14} \mathrm{CO}_{2}$-evolving and trapping reaction flask (Al Abras et al, 1988a). About $50 \mathrm{mg}$ of fresh mycorrhizae were incubated in $5 \mathrm{ml}$ of distilled water containing $10 \mathrm{nmol}$ of [1${ }^{14} \mathrm{C}$ ]glucose $(0.5 \mu \mathrm{Ci})$ at $20{ }^{\circ} \mathrm{C}$. An air-flow of $200 \mathrm{ml} / \mathrm{min}$ was maintained and ${ }^{14} \mathrm{CO}_{2}$ was collected over $90 \mathrm{~min}$. Antibiotics were added to the incubation solution at the following concentrations to prevent bacterial activity: penicillin $12.5 \mathrm{mg} / \mathrm{l}$, streptomycin $25 \mathrm{mg} / \mathrm{l}$ and aureomycin $5 \mathrm{mg} / \mathrm{l}$. Effluent air was passed directly into a $\mathrm{CO}_{2}$-trapping scintillation fluid (CarbomaxKontron) in 10-ml vials and counted. After $90 \mathrm{~min}$ incubation, radiolabel was also determined in methanol/water (70:30, v:v) extracts of mycorrhizae (soluble compounds). Results are presented as means of 4 subsamples with confidence intervals $(P=0.05)$ and are expressed as picomoles of ${ }^{14} \mathrm{CO}_{2}$ produced, or as picomoles of ${ }^{14} \mathrm{C}$ incorporated or absorbed/mg dry weight.

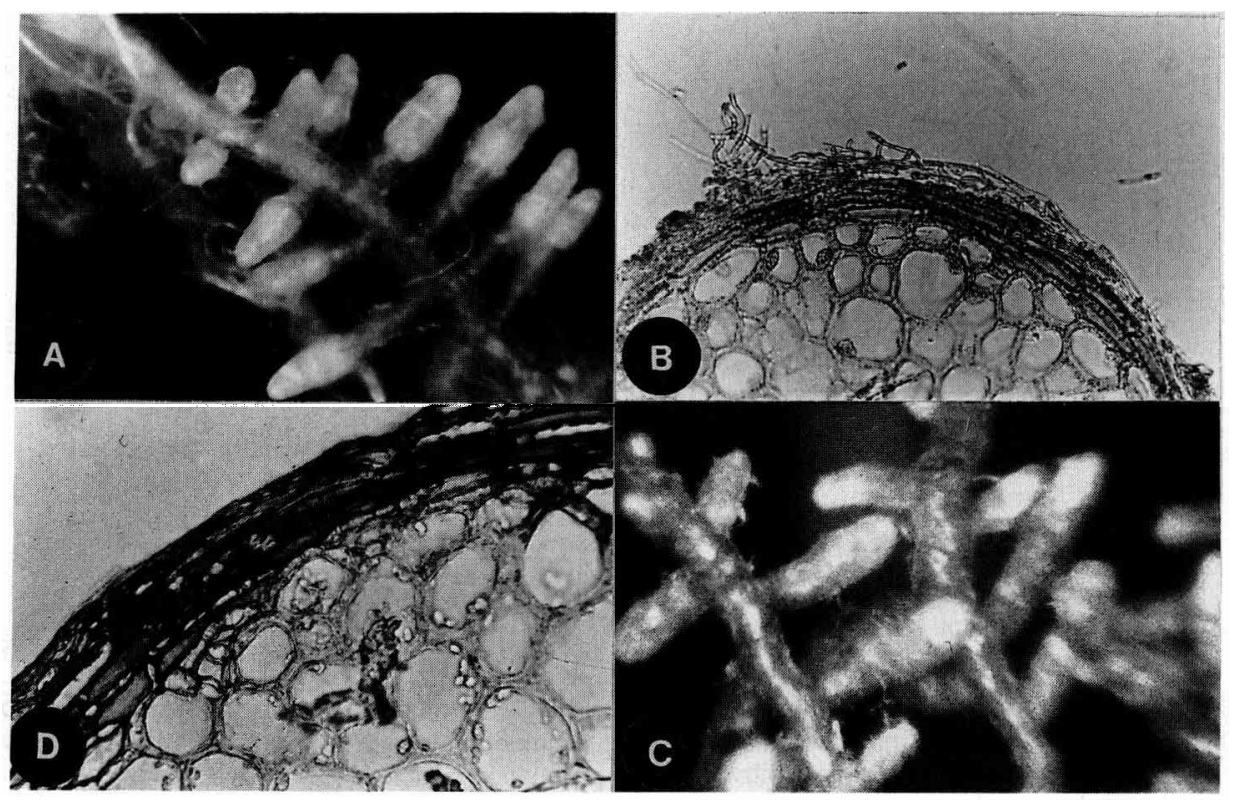

Fig 1. Ectomycorrhizae formed on Norway spruce by 2 ectomycorrhizal fungi. (a) Stereomicrograph of A12 type. (b) Transverse section through A12 type. (c) Stereomicrograph of B00 type. (d) Transverse section through $\mathrm{BOO}$ type. 


\section{RESULTS}

Before storage, type B00 mycorrhizas released $50 \%$ less ${ }^{14} \mathrm{CO}_{2}$ than the $\mathrm{A} 12$ type (fig 2). Storage at $4{ }^{\circ} \mathrm{C}$ in closed polyethylene bags for 2 weeks did not modify the $\mathrm{CO}_{2}$ release by either mycorrhizal type (fig 2). By contrast, storage without a bag at $4{ }^{\circ} \mathrm{C}$ and $98 \%$ humidity reduced ${ }^{14} \mathrm{CO}_{2}$ release by $50 \%$ in B00 type and by $75 \%$ in A12 type (fig 2). Storage at $-4{ }^{\circ} \mathrm{C}$ modified the $\mathrm{CO}_{2}$ release by the $\mathrm{A} 12$ type only, $(-50 \%)$, while the $\mathrm{CO}_{2}$ release by $\mathrm{B} 00$ type was not significantly reduced.

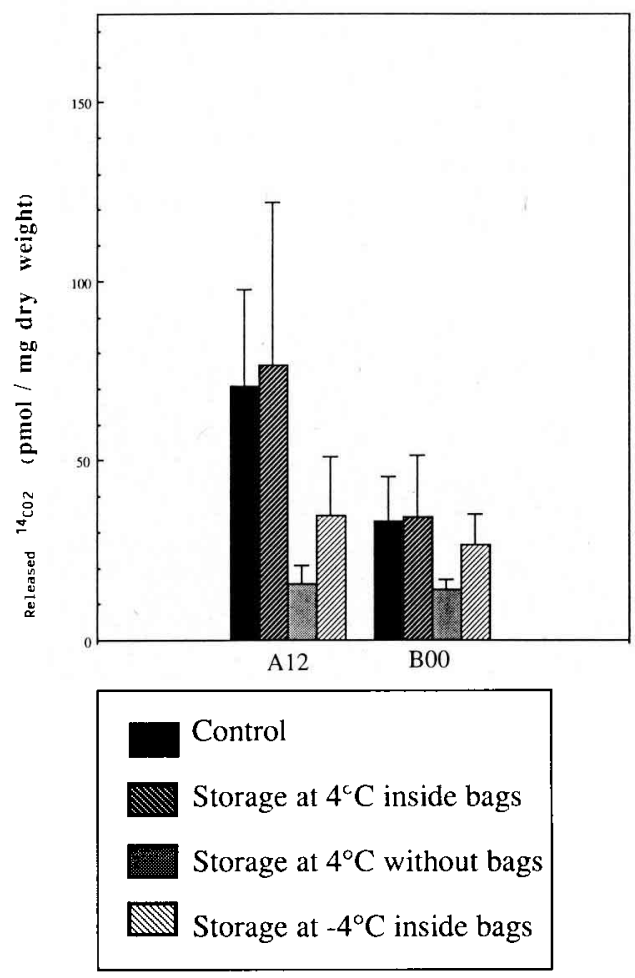

Fig 2. Cumulative release of ${ }^{14} \mathrm{CO}_{2}$ from $[1-14 \mathrm{C}]$ glucose over a $90-\mathrm{min}$ incubation period at $22^{\circ} \mathrm{C}$, by 2 types of ectomycorrhizae ( $A 12$ and $\mathrm{B} 00$ ) after 0 or 2 weeks' cold storage under 3 different conditions. Vertical bars show confidence limits, $P=0.05$.
Comparing the ${ }^{14} \mathrm{C}$ incorporation, the same conclusions can be drawn, even more obviously as both mycorrhizal types incorporated the same level of ${ }^{14} \mathrm{C}$ before storage (fig 3). Storage at $4{ }^{\circ} \mathrm{C}$ in polyethylene bags had no effect on ${ }^{14} \mathrm{C}$ incorporation by either mycorrhizal type (fig 3 ). However, storage outside polyethylene bags greatly reduced incorporation, by $85 \%$ in A12 type and 50\% in B00 type (fig 3). Storage at $-4{ }^{\circ} \mathrm{C}$ reduced ${ }^{14} \mathrm{C}$ incorporation in A12 type only (-30\%) (fig 3 ).

The ${ }^{14} \mathrm{C}$ absorption, last parameter of metabolic activity, integrates ${ }^{14} \mathrm{CO}_{2}$ production and ${ }^{14} \mathrm{C}$ incorporation. Type BOO mycorrhizae absorbed less ${ }^{14} \mathrm{C}$ but were more resilient to storage either at $4{ }^{\circ} \mathrm{C}$ in the absence of polyethylene bag or at $-4{ }^{\circ} \mathrm{C}$, than the $\mathrm{A} 12$ type (fig 4). Two weeks storage at $4{ }^{\circ} \mathrm{C}$ in polyethylene bag did not alter ${ }^{14} \mathrm{C}$ absorption by ectomycorrhizae (fig 4).

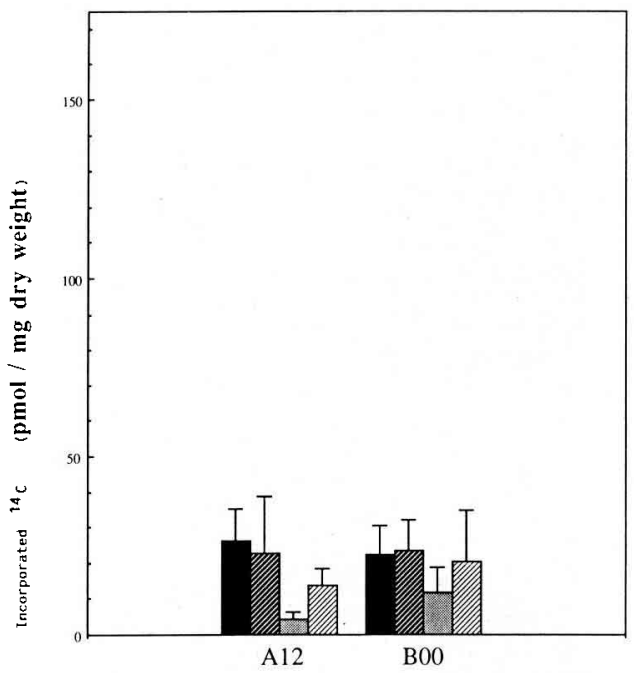

Fig 3. Cumulative ${ }^{14} \mathrm{C}$ incorporation in soluble compound from $\left[1-{ }^{14} \mathrm{C}\right]$ glucose over a $90-\mathrm{min}$ incubation period at $22^{\circ} \mathrm{C}$ by 2 types of ectomycorrhizae (A12 and B00) after 0 or 2 weeks' cold storage under 3 different conditions. Vertical bars show confidence limits, $P=0.05$. 


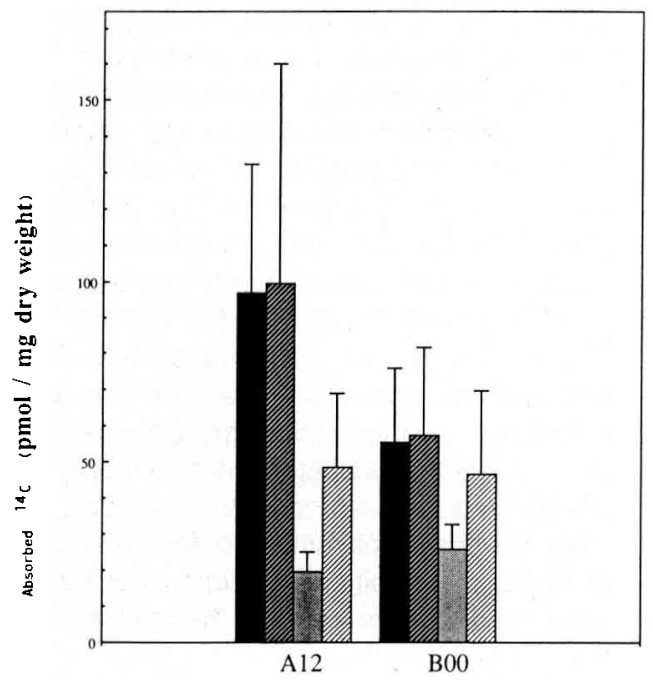

Fig 4. Cumulative ${ }^{14} \mathrm{C}$ incorporation from [1-14C]glucose over a $90-\mathrm{min}$ incubation period at $22^{\circ} \mathrm{C}$, by 2 types of ectomycorrhizae (A12 and $\mathrm{BO0}$ ) after 0 or 2 weeks' cold storage under 2 different conditions. Vertical bars show confidence limits, $P=0.05$.

\section{DISCUSSION}

Regardless of mycorrhizal status, field experiments provide sometimes contradictory results, probably due to the diversity of nursery soils and nursery practice, storage and plantation conditions for bare root seedlings, and the different requirements for each tree species. Lanquist and Doll (1960) indicated that pine and Douglas fir seedlings can be stored in polyethylene bags at low temperature for $\approx 6$ months without noticeable adverse effect on survival or vigor after planting. Similarly, Tisserat and Kuntz (1984) recommended cold storage of Black walnut at $3{ }^{\circ} \mathrm{C}$ in bags. Harvey (1961) observed that survival of Sugar pine after planting was reduced when explants were stored in vapor barrier paper bag with top exposed, at $1.5^{\circ} \mathrm{C}$ during 5 1/2 months compared with freshly lift- ed seedlings. Hee (1987) recommend storage of seedlings at $-2{ }^{\circ} \mathrm{C}$, and Mullin (1980) recommend storage of Red pine between $-1{ }^{\circ} \mathrm{C}$ and $-3^{\circ} \mathrm{C}$ but not at $-18^{\circ} \mathrm{C}$.

Factors other than the storage condition should also be considered, as Venator (1985) showed that the survival of Shortleaf pine seedlings after cold storage is highly dependent on the date of lifting. Kahler and Gilmore (1961) consider that survival of Loblolly pine depends on the physiological state of the seedlings, rather than on the storage conditions. It has been confirmed, in the absence of a storage period, that transplant shock intensity depends on seedling physiology before lifting (Guehl et al, 1989; Kaushal and Aussenac, 1989). In the present study, it should be noted that lifting occurred rather late in spring, which is not exceptional for climatic reasons.

Diversity in field results reinforces the necessity of relating physiological studies to plant behavior after outplanting. The ectomycorrhizal metabolic activity after storage, assessed by radiorespirometry, could be an interesting criterion for seedling evaluation after storage and before plantation.

Indeed, according to our results, among the methods compared, only cold storage at $4{ }^{\circ} \mathrm{C}$ in polyethylene bags maintained ectomycorrhizae in a condition such that metabolic activity was fully restored a few $h$ after returning the seedlings to room temperature. Only 2 papers have previously considered the consequences of storage on ectomycorrhizal survival (Marx, 1979; Alvarez and Linderman, 1983). The ectomycorrhizae of Pinus ponderosa / Pisolithus tinctorius were dead after 5 months' cold storage without polyethylene bags (Alvarez and Linderman, 1983) while the ectomycorrhizae of Pinus echinata / Pisolithus tinctorius remained alive after 4 months' cold storage in polyethylene bags (Marx, 1979). The time scale used in both studies makes it difficult to compare them. 
However, their results seem to confirm our observations based on ectomycorrhizae metabolic activity assessment after 2 weeks storage inside or outside polyethylene bags.

Furthermore, different mycorrhizal types react differently to storage. When storage conditions were adverse (outside polyethylene bags), type B00 mycorrhizae maintained a metabolic activity closer to normal than the type A12. This can be related to field experiments where the mycorrhizal populations during the first year after transplantation in the original nursery site have been assessed (Al-Abras et al, 1988b). Indeed, it has been possible to show than following 2 weeks storage (at $4^{\circ} \mathrm{C}$ outside polyethylene bags), type A12 mycorrhizae, which were dominant on the seedlings before lifting, rapidly disappeared from the root system after transplanting. At the same time, the Boo type, a secondary type, became dominant in the root system after transplanting. By contrast, mycorrhizal populations remained fairly stable on seedlings kept in the nursery. When the seedlings were lifted and immediately transplanted on the same site the same population redistribution as after storage occurred but to a lesser extent: the mycorrhizal type BO0 became dominant, while the A12 type became secondary. Such specific behavior of mycorrhizae has also been observed by Alvarez and Linderman (1983): Pisolithus tinctorius ectomycorrhizae died, but those of a The/ ephora $\mathrm{sp}$ as well as ectendomycorrhizae remained alive after 5 months' cold storage.

It is likely that mycorrhizae may have different requirements for plant carbohydrates and that they may react specifically to any lowering of this supply from the plant. Indeed, some authors have recorded the consumption of carbohydrate by plants during cold storage in darkness
(Ronco, 1973; McCracken, 1979a). From transverse sections it was possible to microscopically visualize the disappearance of root cell starch reserves in A12 ectomycorrhizae after 5 weeks' storage at $4^{\circ} \mathrm{C}(\mathrm{Al}$ Abras, 1988). Decrease of the carbohydrate reserves induced by respiratory consumption could negatively affect plant survival (Hellmers, 1962; Ritchie, 1982), as well as mycorrhizal metabolic activity. The above observations suggest that for controlled nursery inoculation, mycorrhizal fungi could also be selected on their ability to resist lifting and storage stress. It can be assumed that such fungi would quickly restore the plant soil connections after transplanting and thus reduce the severity of transplanting stress.

\section{ACKNOWLEDGMENTS}

We would like to thank the Kappel nursery (57550 Merten, France) for providing Norway spruce seedlings used in this study, D Vairelles for valuable technical assistance and $B$ Dell for critical reading of the manuscript.

\section{REFERENCES}

Al Abras K (1988) La crise de transplantation chez l'épicéa commun, analyse du comportement des mycorhizes. Thesis, Université Nancy I, p 159

Al Abras K, Bilger I, Martin F, Le Tacon F, Lapeyrie $F$ (1988a) Morphological and physiological changes in ectomycorrhizas of spruce (Picea excelsa (Lam) Link) associated with ageing. New Phytol 110, 535-540

Al Abras K, Lapeyrie F, Le Tacon F, Martin F (1988b) Appréciation de la qualité des systèmes racinaires des plants forestiers par leur état symbiotique. Incidence sur la crise de transplantation de l'épicéa commun. Rev For Fr XL 40, 140-148

Alvarez IF, Linderman RG (1983) Effects of ethylene and fungicide dips during cold stor- 
age on root regeneration and survival of western conifers and their mycorrhizal fungi. Can J For Res 13, 962-971

Cannell MGR, Tabbush PM, Deans JD, Kollingsworth MK, Sheppard LJ, Philipson JJ, Murray MB (1990) Sitka spruce and Douglas fir seedlings in the nursery and in cold storage: root growth potential, carbohydrate content, dormancy, frost hardiness and mitotic index. Forestry 63, 9-27

Cossitt FM (1961) Seedling storage in bales. Tree Planters' Notes 45, 11-12

Cram WH, Lindquist $\mathrm{CH}$ (1982) Refrigerated storage for hardwood cuttings of willow and poplar. Tree Planters' Notes 33, 3-5

Guehi JM, Falconnet G, Gruez J (1989) Caractéristiques physiologiques et survie après plantation de plants de Cedrus atlantica élevés en conteneurs sur différents types de substrats de culture. Ann Sci For 46, 1-14

Harvey GM (1961) Effects of refrigeration and shipping on Sugar pine field survival. Tree Planters' Notes 45, 17

Hee SM (1987) Freezer storage practices at Weyerhaeuser nurseries. Tree Planters' Notes $38,7-10$

Hellmers $H$ (1962) Physiological changes in stored pine seedlings. Tree Planters' Notes $53,9-10$

Kahler LH, Gilmore AR (1961) Field survival of cold stored Loblolly pine seedlings. Tree Planters' Notes 45, 15-16

Kaushal P, Aussenac G (1989) Transplanting shock in Corsican pine and cedar of Atlas seedlings: internal water deficit, growth and root regeneration. For Ecol Manage 27, 2940

Lanquist KB, Doll JH (1960) Effect of polyethylene and regular packing methods on Ponderosa pine and Douglas fir seedlings stored overwinter. Tree Planters' Notes 42, 29-30

Marx DH (1979) Pisolithus ectomycorrhizae survive cold storage on Shortleaf pine seedlings. US For Serv Res Note SE-281

McCracken IJ (1979a) Packaging and cool storage of tree seedlings. NZJ For 24, 278-287
McCracken IJ (1979b) Changes in the carbohydrate concentration of pine seedlings after cool storage. NZJ For Sci 9, 34-43

Mullin RE (1966) Overwinter storage of baled nursery stock in northern Ontario. Commun For Rev 45, 224-230

Mullin RE (1971) Some effects of root dipping, root exposure and extended planting dates with White spruce. For Chron 47, 90-93

Mullin RE (1974) Effects of root exposure on establishment and growth of outplanted trees. In: 2nd Int Symp Ecol Physiol Root Growth. Akademie-Verlag, Berlin, 229-242

Mullin RE (1980) Water dipping and frozen overwinter storage of Red and White pine. Tree Planters' Notes 31, 25-28

Mullin RE (1983) A test of the polybin for frozen overwinter storage of Red pine. Tree Planters' Notes 34, 3-6

Mullin RE, Parker JD (1974) Bales versus polybags in cold and frozen overwinter storage of nursery stock. Can J For Res 4, 254-258

Nelson EA (1980) Survival of Western hemlock seedlings after cold storage. Tree Planters' Notes 31, 21-24

Ritchie GA (1982) Carbohydrate reserves and root growth potential in Douglas fir seedlings before and after cold storage. Can J For Res 12, 905-912

Ritchie GA, Roden JR, Kleyn N (1985) Physiological quality of Lodgepole pine and interior spruce seedlings: effects of lift date and duration of freezer storage. Can $J$ For Res 15, 636-645

Ronco $F$ (1973) Food reserves of Engelmann spruce planting stock. For Sci 19, 213-219

Tisserat N, Kuntz JE (1984) Root deterioration of Black walnut seedlings during overwinter storage in Wisconsin. Tree Planters' Notes $35,31-35$

Venator CR (1985) Survival of Shortleaf pine (Pinus echinata Mill) seedlings as influenced by nursery handling and storage. Tree Planters' Notes 36, 17-19

Wycoff $H(1960)$ Refrigerated storage of nursery stock. Tree Planters' Notes 42, 31-32 